\title{
LAJU HIDROLISIS HEROIN DALAM AIR DAN PLASMA
}

\author{
I M. A. G. Wirasuta*, M. A. Ningtyas, E. I. Setyawan \\ Program Studi Farmasi, Fakultas Matematika dan Ilmu Pengetahuan Alam, Universitas Udayana \\ Jimbaran, Bali, Indonesia \\ *e-mai: gelgel.wirasuta@unud.ac.id
}

\begin{abstract}
ABSTRAK
Heroin terhidrolisis secara spontan di dalam air dan darah. Proses ini dapat berpengaruh pada hasil akhir penetepan kadar, khususnya pada anaisis drug profiling. Spektrofotodensitometri digunakan untuk uji drug profiling sediaan heroin ilegal. Dalam penelitian ini dilaporkan analisis heroin, asetilkodein, 6-monoasetilmorfin (6-MAM) dan morfin menggunakan TLC-Spektrofotodensitometri dan pemanfaatannya untuk mentukan laju hidrolisis heroin dalam air dan plasma. Heroin, acetilkodein, 6-MAM, dan morfin dapat dipisahkan dengan baik menggunakan fase gerak campuran pelarut: toluen: sikloheksan:dietilamin (75:15:10, v/v). Batas deteksi penetapankadar heroin menggunakan Al-TLC Si GF ${ }_{254}$ spektrofotodensitometri pada $\lambda 212 \mathrm{~nm}$ adalah 165,16 ng/spot, sedang batas kuantisasinya adalah 550,53 ng/spot. Heroin dalam air terhidrolisis mengikuti reaksi orde pertama dengan tetapan laju $0.055 \mathrm{~min}^{-1}$ dan waktu paruh 12,47 menit, sedangkan di plasma laju hidrolsisnya lebih lambat dengan waktu paruh 16 menit.
\end{abstract}

Kata kunci: Heroin, TLC-spektrofotodensitometri, laju hodrolisis

\begin{abstract}
Heroine is hydrolyzed spontaneously in water and plasma. This will influence the determination, especially on the drug profiling. Spectrophotodensitometry has been used to analyze drug profiling of illicit heroine. This article reports the AL-TLC separation of heroine, 6-monoacetylmorphine (6-MAM), morphine, acetyl codeine, and the heroine hydrolysis in water and plasma. Heroin, 6-MAM, morphine, and acetyl codeine can be wellseparated by mobile phase of toluene:siclohexane:diethyl amine $(75: 15: 10$, v/v). The limit of detection was $165.16 \mathrm{ng} / \mathrm{spot}$ and the limit of quantification was $550.55 \mathrm{ng} / \mathrm{spot}$. Heroine was hydrolyzed in water and plasma under first order reaction. The rate of reaction was $0.55 \mathrm{~min}^{-1}$ in water with the half time reaction of 12.47 minutes. On the other hand the hydrolysis rate in plasma was slower with the half time of 16 minutes.
\end{abstract}

Keywords : hydrolysis, heroin, water, TLC-spectrophotodensitometer

\section{PENDAHULUAN}

Heroin adalah naroktika golongan I. Morfin direaksikan dengan asam asetat anhidrat membentuk diasetilmorfin (heroin). Heroin terhidrolisis secara spontan di dalam lingkungan berair membentuk 6monoasetilmorfin. Waktu paruh alu hidrolisis ini berkisar sekitar 3 menit (Bogus, 2001) Hidrolisis 6-monoasetilmorfin berlangsung lebih lambat berkisar 10-50 menit (Osborne et al., 1990).

Drug profiling adalah analisis khrakterisasi sifat fisika dan kimia narkotika illegal, yang meliputi elusidasi kandungan kimia sediaan narkotika menggunakan metode kromatografi. Komposisi kandungan kimia narkotika, yang tersusun dalam puncak-puncak kromatogram, dapat dilihat sebagai profil kromatogram atau profil sidik jari narkotika tersebut. Profil kromatogram ini dianalisa kedekatanya menggunakan analisis multivariat dan dikelompokkan berdasarkan kemiripan kandungan dan komposisi jumlah kandungannya (Wirasuta, 2012). Pengelompokan dapat dimanfaatkan oleh polisi narkotika guna menelusuri jalur peredarannya.

Hidrolisis selama proses analisis dapat mengakibatkan perbedaan komposisi kandungan heroin, seperti penurunan kadar heroin yang terdeteksi, terdeteksinya 6-MAM atau morfin sebagai senyawa hasil urai selama proses analisis atau peredarannya. Perubahan komposisi ini dapat memberikan perbedaan karekteristik drug profiling, sehingga memberikan kesalahan identitas sidik kromatografi heroin. Kesalahan akan berpengaruh pada pengelompokan dan 
prunutan jalur peredaran naroktika. Dalam penelitian ini dilaporkan laju hidrolisis heroin di dalam lingkungan air menggunakan ALTLC spektrofotodensitometri.

\section{MATERI DAN METODE}

\section{Bahan}

Bahan-bahan yang digunakan antara lain morfin $\mathrm{HCl}$ dan dekstrometorfan $\mathrm{HBr}$ diperoleh dari PT Kimia Farma. Semua pelarut dan pereaksi kimia yang digunakan adalah dengan derajat pro analisis: etanol, metanol, kloroform, dietilamin, ammonia, toluen, aseton, sikloheksan, natrium hidroksida, natrium klorida, isopropanol, dan $\mathrm{KH}_{2} \mathrm{PO}_{4}$. Plat kromatografi lapis tipis silika $\mathrm{GF}_{254}$ dengan ketebalan $0,25 \mathrm{~mm}$, pelat kromatografi lapis tipis kinerja tinggi silika $\mathrm{GF}_{254}$ dengan ketebalan 0,2 $\mathrm{mm}$, kertas saring nitrous cellulose (Whatman).

\section{Peralatan}

Alat yang digunakan dalam penelitian meliputi alat-alat gelas yang umum digunakan
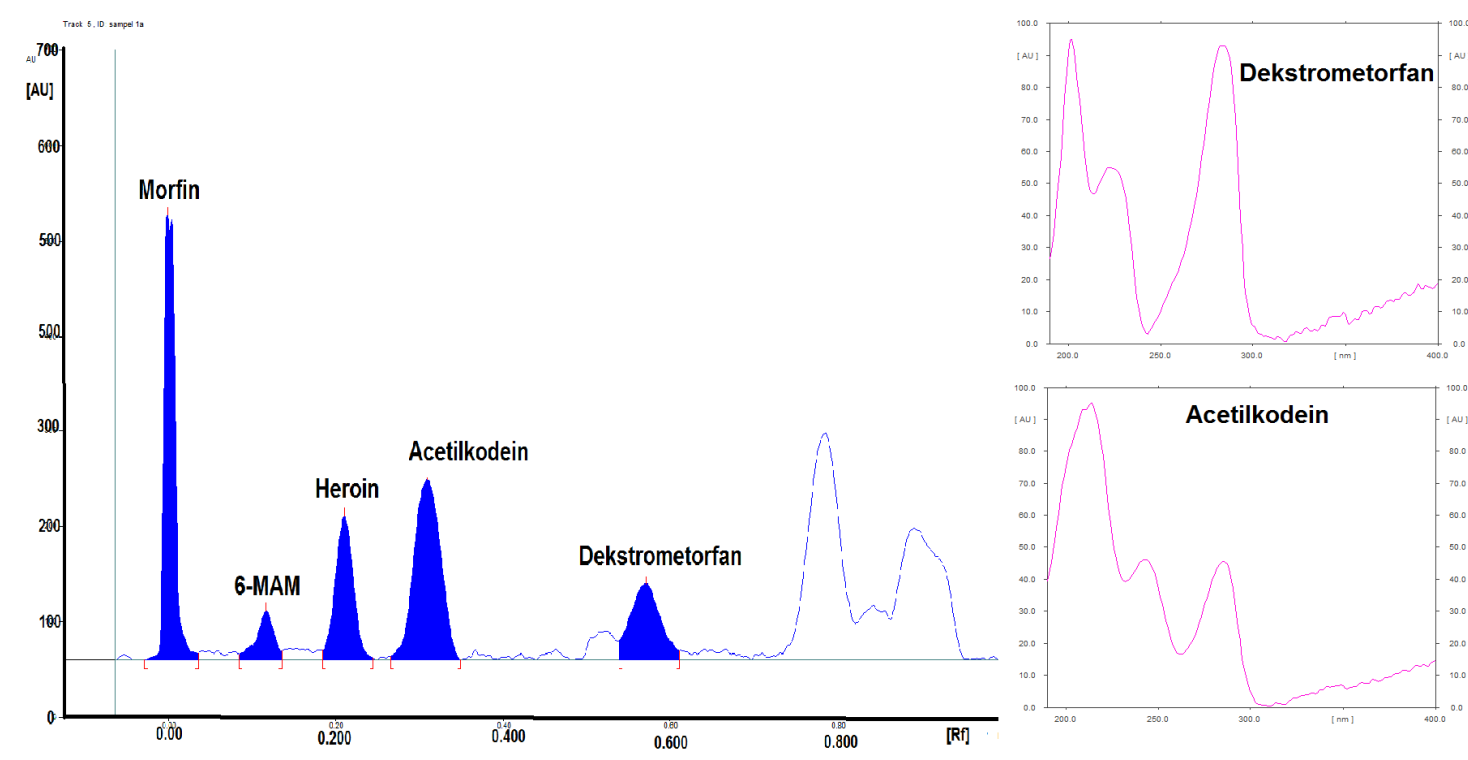

Sintesa heroin.

Morfin $\mathrm{HCl}$ sebanyak $1 \mathrm{~g}$ dimasak dengan asam asetat anhidrat sebanyak $10 \mathrm{~mL}$ menggunakan alat sokhlet di atas kompor langsung selama 9 jam. Campuran ditambahkan larutan Na-karbonat hingga tidak berbuih dan ditambahkan amoniak pekat sedikit demi sedikit hingga terbentuk endapan. Endapan yang terbentuk lalu disaring menggunakan kertas saring whatman dan dikeringkan di dalam oven pada suhu $70^{\circ} \mathrm{C}$ hingga diperoleh serbuk. .
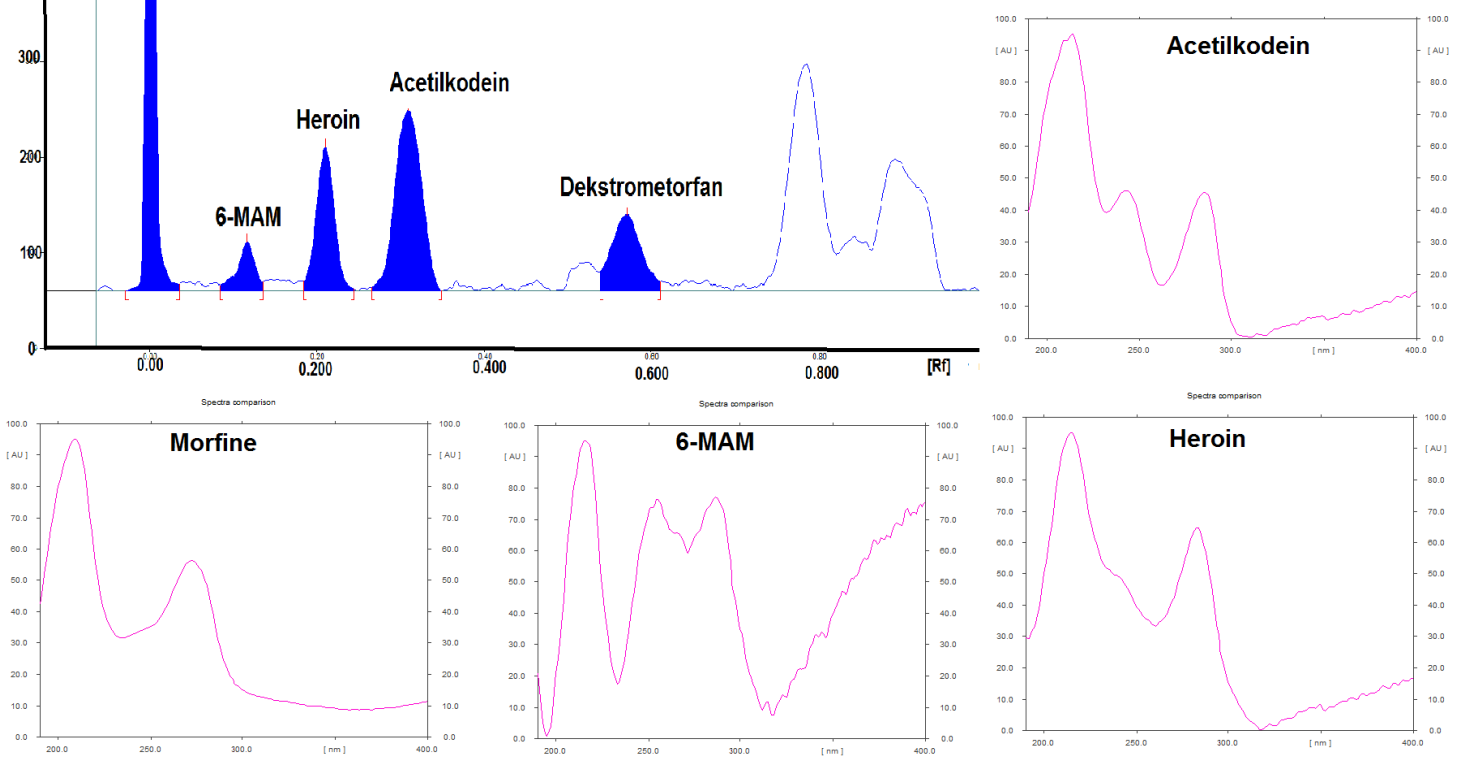

Gambar 1. Densitogram dan in-situ spektrum pemisahan Morfin, 6-Monoacetilmorfin (6-MAM), Heroin, Acetilkodein dan Dekstrometrofan 


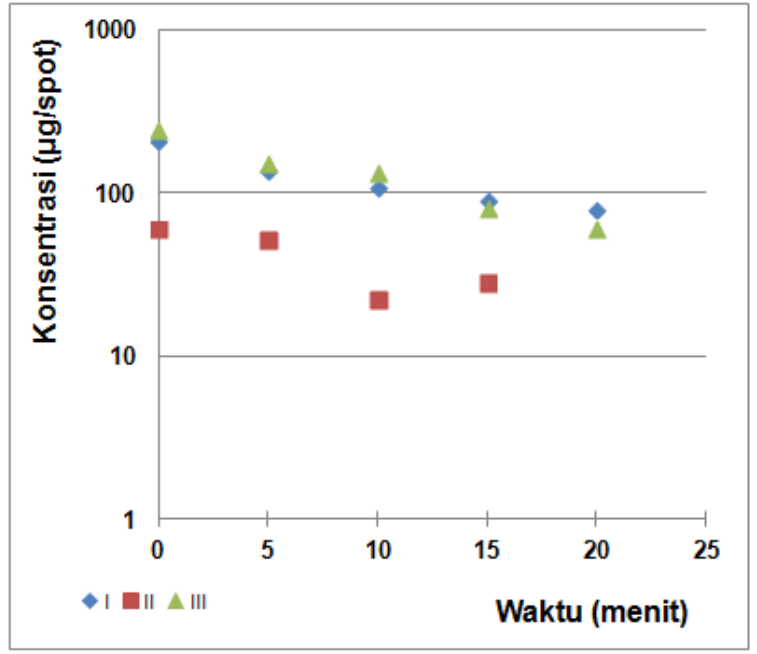

1 (a)

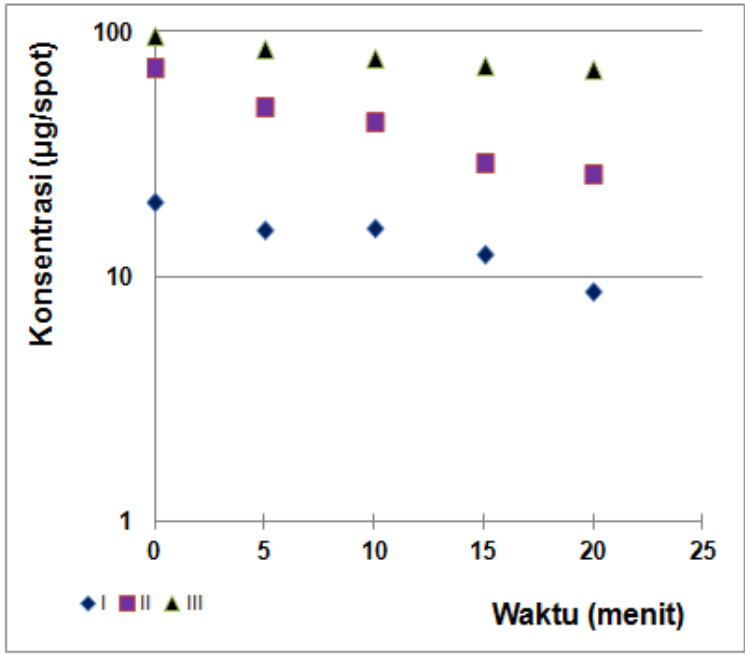

2 (a)

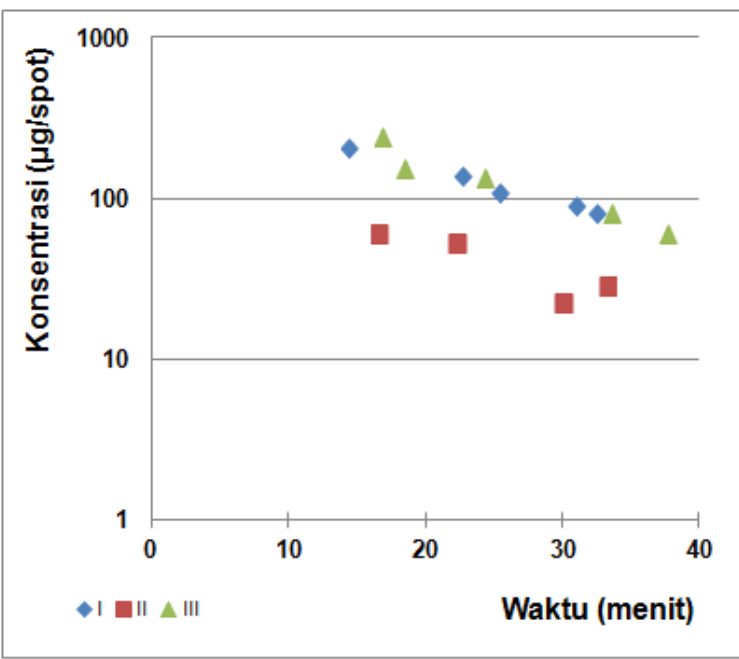

1 (b)

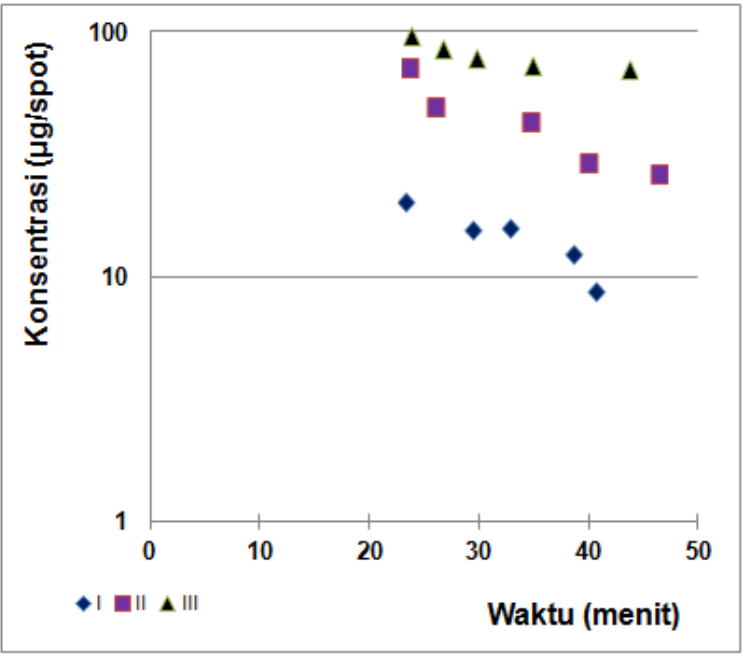

2 (b)

Gambar 2. Profil konsentrasi hidrolisis heroin dalam air 1 (a-b) dan dalam plasma (2 (a-b)

Penentuan batas deteksi (LOD) dan batas kuantitasi (LOQ).

Larutan heroin dengan konsentrasi 25 , 100, dan $150 \mathrm{ng} / \mu \mathrm{L}$ dengan internal standard dekstrometorfan $160 \mathrm{ng} / \mu \mathrm{L}$ di totolkan sebanyak $10,0 \quad \mu \mathrm{L}$ pada plat AL-TLC menggunakan Linomat V (Camag). Chember dijenuhkan dengan campuran pelarut: toluen: sikloheksan:dietilamin $(75: 15: 10, \mathrm{v} / \mathrm{v})$ selama 30 menit, kemudian dielusi hingga tanda batas. Plat kemudian dikeringkan dengan oven pada suhu $60^{\circ} \mathrm{C}$ selama 10 menit. Plat dipindai dengan TLC-Scanner 3 dengan panjang gelombang $212 \mathrm{~nm}$. Luas area dari masingmasing sampel dan konsentrasi dicatat dan dihitung batas deteksi dan kuantitasinya.

\section{Prosedur Hidrolisis}

Dibuat 3 seri konsentrasi larutan campuran heroin dan dekstrometorfan, yaitu: A: $240 \mu \mathrm{g} / \mathrm{ml}$ heroin dan $160 \mu \mathrm{g} / \mathrm{ml}$ dekstrometorfan; B: $288 \mu \mathrm{g} / \mathrm{ml}$ heroin dan $160 \mu \mathrm{g} / \mathrm{ml}$ dekstrometorfan, C: $400 \mu \mathrm{g} / \mathrm{ml}$ heroin dan $160 \mu \mathrm{g} / \mathrm{ml}$ dekstrometorfanLaju hidrolisis dalam air: Lima belas tabung reaksi disiapkan untuk masing-masing seri konsentrasi larutan campuran heroin. Lima belas seri pertama ditambahkan $120 \mu \mathrm{L}$ larutan seri A, 15 tabung resi kedua ditambahkan 120 $\mu \mathrm{L}$ seri $\mathrm{B}$, dan 15 tabung reaksi seri ketiga ditambahkan $120 \mu \mathrm{L}$ seri C. Setiap tbung reaksi ditambahkan $2 \mathrm{~mL}$ air kemudian diinkubasi pada suhu $37{ }^{\circ} \mathrm{C}$. Sampling dilakukan pada rentang waktu $0,5,10,15$, dan 
20 menit. Setiap sampling diambil 3 tabung reaksi dari masing-masing seri.

\section{Dalam media plasma}

Seperti pada percobaan laju hidrolisis heroin dalam air, setiap tabung reaksi yang telah berisi $120 \mu \mathrm{L}$ larutan campuran heroin ditambahkan $2 \mathrm{~mL}$ cairan plasma. Sampling dan inkubasi dilakukan seperti pada percobaan laju hidrolisi dalam air.

\section{Ekstraksi:}

Sebanyak $0,5 \mathrm{~mL}$ larutan incobasi heroin dalam air dipindahkan kedalam tabung ekstraksi yang baru, kemudian ditambahkan 1 $\mathrm{mL}$ larutan 0,2 M buffer fosfat $\mathrm{pH} 9,3$, dan 4 $\mathrm{mL}$ campuran: isopropanol:klorofom (1:3). Ekstraksi heroin dari larutan plasma dilakukan dengan mengambil $0,5 \mathrm{~mL}$ larutan percobaan plasma, ditambahkan $1 \mathrm{~mL}$ larutan $0,2 \mathrm{M}$ buffer fosfat $\mathrm{pH}$ 9,3, 1 gram $\mathrm{NaCl}$, dan $4 \mathrm{~mL}$ campuran: isopropanol:klorofom (1:3). Campuran larutan dikocok dengan pengaduk pada $3000 \mathrm{rpm}$ selama 5 menit, emulsi dipisahkan dengan sentrifugasi selama 5 menit dengan kecepatan $3000 \mathrm{rpm}$. Fase klorofom dipisahkan dan sebanyak $25 \mu \mathrm{L}$ di totolkan pada plat Al-TLC silika $\mathrm{GF}_{254}$ menggunakan linoman V. Plat dielusi seperti pada prosedur penetapan LOD dan LOQ.

\section{Analisis Data.}

Konsentrasi heroin pada masing-masing interval waktu, ditentukan nilai tetapan laju reaksi $(k)$ dengan plot dalam grafik semilogaritme vs waktu inkubasi. Tetapan $k$ dihitung menggunakan reaksi orde ke pertama.

\section{HASIL DAN PEMBAHASAN}

Tabel 1. Validasi metode KLT

\begin{tabular}{|l|l|}
\hline $\mathrm{RS}_{\text {morfin:6-MAM }}$ & 1,8 \\
\hline $\mathrm{RS}_{\text {6-MAM:heroin }}$ & 1,2 \\
\hline $\mathrm{RS}_{\text {heroin:acetilkodein }}$ & 1,1 \\
\hline $\mathrm{RS}_{\text {acetilkodein:dekstrometorfan }}$ & 3,6 \\
\hline Persamaan regresi & $\mathrm{y}=0,0033 \mathrm{x}+0,1888$, \\
\hline Koefisien regrasi & 0,996 \\
\hline $\mathrm{LOD}$ & $165,16 \mathrm{ng} / \mathrm{spot}$ \\
\hline $\mathrm{LOQ}$ & $550,53 \mathrm{ng} / \mathrm{spot}$ \\
\hline Perolehan kembali & $88,61 \pm 12,93 \%$ \\
\hline
\end{tabular}

Tabel 1 menampilkan hasil validasi metode analisis yang digunakan, sedangkan gabar 1 menggambarkan hasil pemisahan sistem KLT. Fase gerak mampu memisahkan senyawasenyawa uji dengan baik RS> 1 . Dekstrometorfan terpisah jauh dari senyawa morfin, 6-MAM, heroin dan acetilkodein, sehingga tepat digunakan sebagai internal standar dalam ekstraksi hasil hidrolisis heroin. Koefisien regrasi mendekati 1 menggambarkan respon alat pada rentang pengukuran $\lambda=212$ adalah sangat linear. Perolehan kembali menggunakan internal standar memenuhi kriteria persentase perolehan kembali menurut FDA yaitu antara $80-120 \%$. Berdasarkan data diatas sistem KLT dapat digunakan untuk menetapkan laju hidrolisis heroin

Tabel 2. Persamaan laju hidrolisis heroin dalam medium air dan plasma

\begin{tabular}{cc|cc}
\hline $\begin{array}{c}\text { Tidak memperhitungkan waktu ekstraksi } \\
\text { Persamaan Regresi }\end{array}$ & $\mathrm{R}^{2}$ & Persamaan Regresi & $\mathrm{R}^{2}$ \\
\hline \multicolumn{4}{c}{ laju hidrolisis dalam medium air } \\
\hline $\mathrm{y}=-0.0297 \mathrm{x}+2.3822$ & 0.9806 & $\mathrm{y}=-0.0225 \mathrm{x}+2.6392$ & 0.9887 \\
$\mathrm{y}=-0.0271 \mathrm{x}+1.7803$ & 0.7093 & $\mathrm{y}=-0.0251 \mathrm{x}+2.2169$ & 0.8258 \\
$\mathrm{y}=-0.0202 \mathrm{x}+2.274$ & 0.9443 & $\mathrm{y}=-0.0251 \mathrm{x}+2.7402$ & 0.9423 \\
\hline \multicolumn{5}{c}{ laju hidrolisis dalam medium plasma } \\
\hline $\mathrm{y}=-0.0166 \mathrm{x}+1.312$ & 0.9078 & $\mathrm{y}=-0.0183 \mathrm{x}+1.7486$ \\
$\mathrm{y}=-0.022 \mathrm{x}+1.8317$ & 0.9686 & $\mathrm{y}=-0.0178 \mathrm{x}+2.2175$ & 0.8682 \\
$\mathrm{y}=-0.007 \mathrm{x}+1.9718$ & 0.9573 & $\mathrm{y}=-0.0178 \mathrm{x}+2.2175$ & 0.9127 \\
\hline
\end{tabular}


Pada Gambar 1 (a) dan 2 (a) tidak mempertimbangkan waktu ekstraksi dan gambar 1(b) dan 1(b) mempertimbangkan waktu dalam perhitungan persamaan laju hidrolisis. Tabel 2 menampilkan persamaan laju hidrolisis dalam medium air dan plasma. Laju hidrolisis heroin mengikuti orde ke pertama baik pada medium air maupun plasma. Heroin dilaporkan terhidrolisis secara spontan dalam medium air dengan laju reaksi orde ke pertama (Smitth et. al. 1978) Pertimbangan memasukkan waktu ekstraksi dalam perhitungan persamaan laju tidak memberi perubahan yang signifikan terhadap koefisien regresi persamaan laju. Hal ini menandakan baik dalam proses einkubasi dan kstraksi heroin terhidrolisi pada orde yang sama. Hidrolisis heroin dalam plasma divasilitasi oleh enzim kolinesterasi (Lockridge, $\mathrm{O}$, et al. 1980). Tetapan laju hidrolisis heroin dalam air lebih tinggi jika dibandingkan dengan dalam plasma. Hal ini menandakan reaksi hidrolisis spontan berlangung lebih cepat jika dibandingkan dengan hidrolisis tervasilitasi oleh enzim. Waktu paruh hidrolisis dalam air berkisar 12-13 menit, sedangkan dalam plasma 16 menit. Waktu paruh yang ditemukan lebih lambat jika dibandingkan pada waktu paruh heroin di dalam tubuh (Bogus, 2001)

Tabel 3. Tetapan Laju hidrolisis heroin dalam air dan plasma

\begin{tabular}{c|c|c}
\hline Variasi & $\mathrm{k}\left(\right.$ menit $\left.^{-1}\right)$ & $\mathrm{t} 1 / 2$ (menit) \\
\hline \multicolumn{3}{|c}{ dalam medium air } \\
\hline I & 0,0518 & 13,39 \\
II & 0,0577 & 12,01 \\
III & 0,0577 & 12,01 \\
\hline \multicolumn{3}{|c}{ dalam medium plasma } \\
\hline I & 0,0421 & 16,47 \\
II & 0,0409 & 16,93 \\
III & 0,0409 & 16,93 \\
\hline
\end{tabular}

\section{KESIMPULAN}

Heroin mengaami hidrolisis spontan dalam medium air dan plasma. Laju hidrolisis relativ lebih lambat di dalam plasma jika dibandingkan pada medium air. Selama proses ekstraksi heroin juga mengalami hidrolisis.

\section{DAFTAR PUSTAKA}

Bogusz, M. J., Maier, R. D., Erkens, M. dan Kohls, U. 2001. Detection of nonprescription heroin markers in urine with liquid chromatography-atmospheric pressure chemical ionization mass spectrometry. J. Anal. Toxicol., 25: 431438.

Lockridge, O, Mottershaw-Jackson, N, Eckerson, H. W, La Du, B. N. 1980. Hydrolysis of diacetylmorphine (heroin) by human serum cholinesterase. $J$ Pharmacol Exp Ther, 215(1):1-8.

Osborne, R,, Joel, S,, Trew, D., UND Slevin, M. 1990. Mophine and metabolite behavior ater different routes of morphine aadministrasion, Determination of the impotance of the active metabolite morphin-6glucoronide, Clin. Pharmacol. ther, 47:12-19.

Smith, P, T,, Hirst, M,, Gowdey, C. W. 197. Spontaneous hydrolysis of heroin in buffered solution, Can $J$ Physiol Pharmacol, 56(4): 665-667.

Wirasuta, I M. A. G. 2012. Chimical profiling of ecstasy recovered from around Jakarta by High Performance Thin Layer Chromatography

(HPTLC)densitometri, Egyptian Journal of Forensic Sciences, 2: 97-104. 